\title{
SLC36 family of proton-coupled amino acid transporters in GtoPdb v.2021.3
}

\author{
Catriona M.H. Anderson ${ }^{1}$ and David T. Thwaites ${ }^{1}$
}

1. Newcastle University, UK

\begin{abstract}
Members of the SLC36 family of proton-coupled amino acid transporters are involved in membrane transport of amino acids and derivatives. The four transporters show variable tissue expression patterns and are expressed in various cell types at the plasma-membrane and in intracellular organelles. PAT1 is expressed at the luminal surface of the small intestine and absorbs amino acids and derivatives [3]. In lysosomes, PAT1 functions as an efflux mechanism for amino acids produced during intralysosomal proteolysis [2, 18]. PAT2 is expressed at the apical membrane of the renal proximal tubule [6] and at the plasma-membrane in brown/beige adipocytes [20]. PAT1 and PAT4 are involved in regulation of the mTORC1 pathway [11]. More comprehensive lists of substrates can be found within the reviews under Further Reading and in the references [3].
\end{abstract}

\section{Contents}

This is a citation summary for SLC36 family of proton-coupled amino acid transporters in the Guide to Pharmacology database (GtoPdb). It exists purely as an adjunct to the database to facilitate the recognition of citations to and from the database by citation analyzers. Readers will almost certainly want to visit the relevant sections of the database which are given here under database links.

GtoPdb is an expert-driven guide to pharmacological targets and the substances that act on them. GtoPdb is a reference work which is most usefully represented as an on-line database. As in any publication this work should be appropriately cited, and the papers it cites should also be recognized. This document provides a citation for the relevant parts of the database, and also provides a reference list for the research cited by those parts. For further details see [7].

Please note that the database version for the citations given in GtoPdb are to the most recent preceding version in which the family or its subfamilies and targets were substantially changed. The links below are to the current version. If you need to consult the cited version, rather than the most recent version, please contact the GtoPdb curators.

\section{Database links}

SLC36 family of proton-coupled amino acid transporters

https://www.guidetopharmacology.org/GRAC/FamilyDisplayForward?familyId=223

Transporters

PAT1(Proton-coupled Amino acid Transporter 1)

https://www.guidetopharmacology.org/GRAC/ObjectDisplayForward?objectId=1161

PAT2(Proton-coupled Amino acid Transporter 2)

https://www.guidetopharmacology.org/GRAC/ObjectDisplayForward?objectId=1162

PAT3(Proton-coupled Amino acid Transporter 3)

https://www.guidetopharmacology.org/GRAC/ObjectDisplayForward?objectId=1163

PAT4(Proton-coupled Amino acid Transporter 4)

https://www.guidetopharmacology.org/GRAC/ObjectDisplayForward?objectId=1164

\section{References}

1. Abbot EL, Grenade DS, Kennedy DJ, Gatfield KM and Thwaites DT. (2006) Vigabatrin transport across the human intestinal epithelial (Caco-2) brush-border membrane is via the $\mathrm{H}+$-coupled amino-acid transporter hPAT1. Br J Pharmacol 147: 298-306 [PMID:16331283] 
2. Agulhon C, Rostaing P, Ravassard P, Sagné C, Triller A and Giros B. (2003) Lysosomal amino acid transporter LYAAT-1 in the rat central nervous system: an in situ hybridization and immunohistochemical study. J Comp Neurol 462: 71-89 [PMID:12761825]

3. Alexander SPH, Kelly E, Mathie A, Peters JA, Veale EL, Armstrong JF, Faccenda E, Harding SD, Pawson AJ and Sharman JL et al.. (2019) THE CONCISE GUIDE TO PHARMACOLOGY 2019/20: Transporters. Br J Pharmacol 176 Suppl 1: S397-S493 [PMID:31710713]

4. Anderson CM, Grenade DS, Boll M, Foltz M, Wake KA, Kennedy DJ, Munck LK, Miyauchi S, Taylor PM and Campbell FC et al.. (2004) H+/amino acid transporter 1 (PAT1) is the imino acid carrier: An intestinal nutrient/drug transporter in human and rat. Gastroenterology 127: 141022 [PMID:15521011]

5. Anderson CM and Thwaites DT. (2005) Indirect regulation of the intestinal H+-coupled amino acid transporter hPAT1 (SLC36A1). J Cell Physiol 204: 604-13 [PMID:15754324]

6. Bröer S, Bailey CG, Kowalczuk S, Ng C, Vanslambrouck JM, Rodgers H, Auray-Blais C, Cavanaugh JA, Bröer A and Rasko JE. (2008) Iminoglycinuria and hyperglycinuria are discrete human phenotypes resulting from complex mutations in proline and glycine transporters. J Clin Invest 118: 3881-92 [PMID:19033659]

7. Buneman P, Christie G, Davies JA, Dimitrellou R, Harding SD, Pawson AJ, Sharman JL and Wu Y. (2020) Why data citation isn't working, and what to do about it Database 2020 [PMID:32367113]

8. Chen Z, Kennedy DJ, Wake KA, Zhuang L, Ganapathy V and Thwaites DT. (2003) Structure, tissue expression pattern, and function of the amino acid transporter rat PAT2. Biochem Biophys Res Commun 304: 747-54 [PMID:12727219]

9. Edwards N, Anderson CM, Gatfield KM, Jevons MP, Ganapathy V and Thwaites DT. (2011) Amino acid derivatives are substrates or non-transported inhibitors of the amino acid transporter PAT2 (slc36a2). Biochim Biophys Acta 1808: 260-70 [PMID:20691150]

10. Edwards N, Anderson CMH, Conlon NJ, Watson AK, Hall RJ, Cheek TR, Embley TM and Thwaites DT. (2018) Resculpting the binding pocket of APC superfamily LeuT-fold amino acid transporters. Cell Mol Life Sci 75: 921-938 [PMID:29058016]

11. Fan SJ and Goberdhan DCI. (2018) PATs and SNATs: Amino Acid Sensors in Disguise. Front Pharmacol 9: 640 [PMID:29971004]

12. Fan SJ, Snell C, Turley H, Li JL, McCormick R, Perera SM, Heublein S, Kazi S, Azad A and Wilson C et al.. (2016) PAT4 levels control amino-acid sensitivity of rapamycin-resistant mTORC1 from the Golgi and affect clinical outcome in colorectal cancer. Oncogene 35: 3004-15 [PMID:26434594]

13. Foltz M, Boll M, Raschka L, Kottra G and Daniel H. (2004) A novel bifunctionality: PAT1 and PAT2 mediate electrogenic proton/amino acid and electroneutral proton/fatty acid symport. FASEB J 18: 1758-60 [PMID:15345686]

14. Kennedy DJ, Gatfield KM, Winpenny JP, Ganapathy V and Thwaites DT. (2005) Substrate specificity and functional characterisation of the $\mathrm{H}+$ /amino acid transporter rat PAT2 (Slc36a2). Br J Pharmacol 144: 28-41 [PMID:15644866]

15. Larsen M, Holm R, Jensen KG, Brodin B and Nielsen CU. (2009) Intestinal gaboxadol absorption via PAT1 (SLC36A1): modified absorption in vivo following co-administration of L-tryptophan. $\mathrm{Br}$ J Pharmacol 157: 1380-9 [PMID:19594759]

16. Metzner L, Kottra G, Neubert K, Daniel H and Brandsch M. (2005) Serotonin, L-tryptophan, and tryptamine are effective inhibitors of the amino acid transport system PAT1. FASEB J 19: 146873 [PMID:16126914]

17. Pillai SM and Meredith D. (2011) SLC36A4 (hPAT4) is a high affinity amino acid transporter when expressed in Xenopus laevis oocytes. J Biol Chem 286: 2455-60 [PMID:21097500]

18. Sagné C, Agulhon C, Ravassard P, Darmon M, Hamon M, El Mestikawy S, Gasnier B and Giros B. (2001) Identification and characterization of a lysosomal transporter for small neutral amino acids. Proc Natl Acad Sci USA 98: 7206-11 [PMID:11390972]

19. Thwaites DT and Anderson CM. (2011) The SLC36 family of proton-coupled amino acid transporters and their potential role in drug transport. Br J Pharmacol 164: 1802-16 [PMID:21501141]

20. Ussar S, Lee KY, Dankel SN, Boucher J, Haering MF, Kleinridders A, Thomou T, Xue R, Macotela Y and Cypess AM et al.. (2014) ASC-1, PAT2, and P2RX5 are cell surface markers for white, beige, and brown adipocytes. Sci Transl Med 6: 247ra103 [PMID:25080478] 